\title{
Rusland og FN
}

Af Flemming Splidsboel Hansen

I russiske politiske kredse har man talt meget om vigtigheden af at respektere den ufortyndede westfalske suverænitet - det 'suveræne demokrati'. På den baggrund kan det virke overraskende, at Rusland overhovedet tilsluttede sig idéen om R2P, og de russiske myndigheder lægger i dag ikke skjul på, at de betragter praksis i forhold til R2P med stor skepsis. Det russiske udenrigsministerium advarer om, at enhver beslutning om intervention skal tages af sikkerhedsrådet, og advarer mod tendensen til at gå uden om sikkerhedsrådet $o g$ i stedet alliere sig med 'gruppen af venner' for at vinde legitimitet for sine aktioner.

\section{Rusland tillægger FN stor betydning.} Det fremgår dagligt af den politiske debat $i$ landet og af udmeldingerne fra Kreml og regeringskontorerne, og det kan ses i de grundlæggende doktriner, som skiftende russiske præsidenter offentliggør for at informere omverdenen om Ruslands væsentligste udenrigs-, forsvars- og sikkerhedspolitiske pejlemærker. Den seneste udenrigspolitiske doktrin, underskrevet af præsident Vladimir Putin den 12. februar 2013, siger fx, at Rusland vil arbejde for "styrkelsen, med alle midler, af den inter- nationale fred og den generelle sikkerhed og stabilitet med henblik på at befæste et retfærdigt og demokratisk internationalt system, som er bygget på (...) jævnbyrdige og partnerskabsagtige forhold mellem landene og under den centrale koordinerende rolle af FN som den grundlæggende organisation, der regulerer internationale forhold".

Tidligere doktriner har haft tilsvarende referencer til FN - til vigtigheden af at fastholde respekten for FN generelt og for sikkerhedsrådet mere specifikt - og det har faktisk været således, siden Rusland i december 1991 overtog Sovjetunionens plads og ansvar og dermed også fik vetoret som ét af de fem permanente medlemmer af Sikkerhedsrådet. På det helt overordnede niveau kan denne russiske politik afspejle principiel støtte til den opridsede verdensorden og/eller et ønske om at maksimere Ruslands indflydelse på et tidspunkt, hvor landet har været relativt svagt, og hvor den særegne konstruktion, som især sikkerhedsrådet er, kunne tjene dets egeninteresser; i realiteten er det dog ikke et sort-hvidt billede med enten selvopofrende idealisme eller kynisk instrumentalisme men snarere en kombination, hvor $\mathrm{fx}$ Ruslands egne midler og omverdenens politik på forskellige tidspunkter

Flemming Splidsboel Hansen er seniorforsker ved Dansk Institut for Internationale Studier. Hans forskningsområder er bl.a. russisk inden- og udenrigspolitik, russisk national identitet, Ukraine, Belarus, SNG og Kaukasus. Han er forfatter til en lang række artikler og kronikker og medforfatter til flere bøger. 
har fået Kreml til at placere landet på forskellige punkter på denne skala fra idealisme til instrumentalisme.

\section{Sikkerhedsrådet}

Sikkerhedsrådet er helt centralt i Ruslands FN-politik. Det permanente medlemskab giver øget indflydelse og højere status.

Begge dele har været - og er - af stor vigtighed for et land, som har været tilskuer til den delvise ommøblering af det internationale system efter ophøret af den kolde krig, og som har kæmpet for at definere en ny rolle og identitet for sig selv siden uafhængigheden i 1991; hvis ikke andet, ja så var man da i det mindste permanent medlem af FN's Sikkerhedsråd, og deri lå i sig selv en vis tryghed foruden også anerkendelse fra andre staters side.

Ruslands utilfredshed med den internationale udvikling efter afslutningen af den kolde krig er velkendt, og førende russiske politikere er blevet stadig mere aktive og skarpe i deres kritik af unilateralismen og det de portrætterer som en USA-kontrolleret verdensorden, hvor FN er blevet et redskab for opportunistiske kræfter, international lov rutinemæssigt tilsidesættes, militær magt benyttes uden tøven, og USA og dets allierede blander sig $i$ andre landes indre forhold, hvor og hvornår det passer dem.

Igen kan man bladre i den udenrigspolitiske doktrin fra 2013 for at finde referencer til dette synspunkt, eller man kan fx genlæse Putins berømte tale fra Sikkerhedskonferencen i München i februar 2007, hvor han gik i et verbalt frontalangreb på USA og den netop skitserede verdensorden og ganske tydeligt fik slået fast, at Rusland ikke længere ville affinde sig med det.

I forsøget på at justere forskellige processer i det internationale system, så det i højere grad end tidligere og selv i dag matcher Ruslands visioner og/eller interesser, gjorde Kreml på et tidligt tidspunkt sikkerhedsrådet til den primære kampplads og vetoretten til det ultimative våben. Senere er den unilaterale militære dimension blevet mere synlig, tydeligst $\mathrm{i}$ forbindelse med beslutningen i september 2015 om at deployere styrker til støtte for Bashar al-Assads styre i Syrien, men sikkerhedsrådet er forblevet dén arena, hvor Rusland mest åbent og direkte forsøger at sætte et aftryk på de dominerende globale politiske standarder.

Vi får et indtryk af Ruslands definition af sig selv og vurdering af sin egen relative formåen ved at se på brugen af vetoretten. Vetokortet blev trukket første gang i 1993, og i alt har Rusland nedlagt veto 13 gange: To gange i 1990'erne, fire gange i 2000'erne og indtil nu syv gange i 2010'erne. Blandt emnerne har fx været situationen i Mellemøsten, udviklingen i og omkring Bosnien-Herzegovina, kritik af diktaturer og senest nu også konflikten i Ukraine. I syv af disse tilfælde har Rusland nedlagt veto alene, mens det seks gange har gjort det sammen med Kina, som synes at føre en mindre konfronterende linje. Vetoretten er i øvrigt blevet benyttet ni gange siden Putins tale i München i februar 2007.

Der tegner sig et billede af et Rusland, som mere klart end tidligere har defineret, hvad det står for, og som i højere grad end tidligere ser sig i stand til at sætte foden ned for at forhindre helt konkrete politikker eller mere abstrakte processer. Som tallene her angiver, så er brugen af vetoretten stadigvæk et forholdsvis sjældent fænomen - men måske også så meget mere effektfuldt pga. netop dette - og afstemningsmønsteret i Generalforsamlingen giver os et mere detaljeret indblik i de mulige ændringer i den russiske politik. 
I forsøget på at justere forskellige processer i det internationale system, så det i højere grad matcher Ruslands visioner og interesser, gjorde Kreml på et tidligt tidspunkt sikkerhedsrådet til den primære kampplads og vetoretten til det utimative våben. Senеге er den unilaterale militære dimension blevet mere synlig, men sikkerhedsrådet er forblevet dén arena, hvor Rusland mest åbent og direkte forsøger at sætte et aftryk på de dominerende globale politiske standarder.

Jeg vil komme ind på dette nedenfor, men inden da skal spørgsmålet om en reform af sikkerhedsrådet kort berøres.

\section{Spørgsmålet om reform}

Indledningsvis blev det bemærket, at især sikkerhedsrådet er en særegen konstruktion. Det er jo en såkaldt koncert, dvs. en institution, hvis adgangskrav er magt, og som samler de mest magtfulde stater i et opgør med FN's princip om 'én stat én stemme. Vi kender måske koncerten bedst fra Wienerkongressen (1814-1815), hvor datidens stærkeste europæiske magter skabte et lille eksklusivt forum, hvor de sammen kunne træffe beslutninger om alle de væsentligste spørgsmål på kontinentet. Rusland var også en del af denne koncert - med tiden måske endog det mest magtfulde medlem - og man har ingen særlige kvaler ved denne type af realpolitiske konstruktioner.

Det betyder dog ikke, at man er blind for diskussionen om en mulig reform af sikkerhedsrådet. Den europæiske koncert fra første halvdel af 1800-tallet blev naturligvis gradvist præget af tidens magtforskydninger, og grundlaget for FN's sikkerhedsråd er også anderledes i dag end ved det første møde i januar 1946. Sejrherrerne fra Anden Verdenskrig har kunnet iagttage, hvorledes nye stater er blevet dannet, økonomier er buldret frem, og befolkninger er vokset dramatisk. Hvis Ruslands tale om et 'retfærdigt og demokratisk internationalt system' skal følges op af konkret handling, ja så er støtte til en re- form af sikkerhedsrådet, fx i form af en udvidelse af antallet af permanente medlemmer, et oplagt sted selv at levere resultater.

Dette er endnu mere så, eftersom Rusland har et forholdsvist tæt samarbejde med flere af de mulige aspiranter. Det drejer sig $\mathrm{fx}$ om Indien, Brasilien og Sydafrika, som sammen med Rusland og Kina indgår i BRIKS (Brasilien, Rusland, Indien, Kina og Sydafrika). De fem medlemsstater hævder ofte, at BRIKS' mission netop er at reformere det internationale system, at give en stemme til den ikke-privilegerede del af verdens befolkning og generelt at udjævne politiske magtforskelle. Som repræsentanter for den tredje verden og henholdsvis Asien, Sydamerika og Afrika kan Indien, Brasilien og Sydafrika med rimelighed forvente, at Rusland vil følge op på de mange skåltaler med reel støtte til disse landes FN-ambitioner.

Intet tyder dog på, at støtten er lige om hjørnet. I Moskva tales ofte og længe om nødvendigheden af at modernisere Sikkerhedsrådet, så det bliver mere repræsentativt for verdens aktuelle tilstand, men der synes langt til handling. Problemet er, at en udvidelse af Sikkerhedsrådet næsten uvægerligt vil føre til en svækkelse af de fem nuværende permanente medlemmers relative indflydelse, og det synes ingen af dem at være villig til at acceptere. Således er også den russiske holdning, at man ikke vil afgive magt og derved mindske sin egen mulighed for at påvirke udviklingen af det internationale system. En 
reform må altså helst ikke ændre noget.

Heldigvis for Rusland synes de fire øvrige permanente medlemmer at dele denne opfattelse, og for dem alle er det derfor forholdsvis let og uforpligtende at tale om reformer, for sandsynligvis vil en anden blokere i sidste ende. Og på den måde kan de alle skiftes til at free-ride og lade andre tage opgørene med de stater, som kæmper for en reform af Sikkerhedsrådet. Set i lyset af såvel Ruslands erklærede modstand mod den påståede unilateralisme og den hyppigere brug af vetoretten forekommer det usandsynligt, at landet vil tillade en egentlig reform af Sikkerhedsrådet.

Et eller flere af de nye mulige vetolande vil muligvis støtte Ruslands politik, men det virker mere sikkert at holde fast i det velkendte snarere end at udfordre skæbnen og måske blive endnu mere isoleret $\mathrm{i}$ konfliktfyldte afstemninger.

\section{Generalforsamlingen}

I Generalforsamlingen er Rusland i den lille østeuropæiske regionale gruppe - eller afstemningsgruppe - sammen med andre tidligere Sovjetrepublikker som Armenien, Aserbajdsjan, Georgien, Hviderusland, Moldova og Ukraine foruden også Estland, Letland og Litauen. De øvrige tidligere Sovjetrepublikker, dvs. Kasakhstan, Kirgisistan, Tadsjikistan, Turkmenistan og Usbekistan er alle i den store asiatiske regionale gruppe med fx Kina, Indien, Iran, Afghanistan og Pakistan. Den praktiske koordination mellem Rusland og flere af dets tætteste allierede kan finde sted på tværs af grupperne og i øvrige fora.

Som nævnt giver afstemningsmønsteret i Generalforsamlingen os et mere detaljeret indtryk af Ruslands egendefinition, således som den kommer til udtryk i udenrigspolitiske handlinger. I første halvdel af 1990'erne stemte Rusland ofte på samme måde som Vesten - lidt bredt defineret men siden er der sket et gradvist skifte, og landet har nærmet sig, hvad nogle kalder "den antihegemoniske blok". Denne udvikling afspejler, hvad Putin betegner en "tilbagevenden til Ruslands ægte interesser", dvs. et opgør med tilnærmelsen til Vesten og et større fokus på at forsvare Ruslands suverænitet og udenrigspolitiske handlerum. Dét har medført en række konkrete ændringer i den russiske politik i Generalforsamlingen.

Mest dramatisk har man kunnet iagttage det $\mathrm{i}$ afstemningerne om Mellemøsten. Rusland har haft et ganske tæet forhold til Israel i årene efter Sovjetunionens sammenbrud, men landets støtte er gradvist blevet forskudt til fordel for især det palæstinensiske selvstyreområde og Syrien. I de mange årlige afstemninger om den israelsk-arabiske konflikt har man således nærmet sig den arabiske og islamiske verden ved $\mathrm{fx}$ i højere grad at stemme for øgede rettigheder til og anerkendelse af det palæstinensiske selvstyreområde og kritisere Israel for dets fremfærd.

Interessant er det også, at Rusland stort set er ophørt med at støtte kritikken af påståede undertrykkende regimer som i fx Nordkorea, Myanmar, Turkmenistan og Zimbabwe. Et meget sigende billede er det forhold, at hvor Rusland i forsamlingerne 47 - $53(1992$ - 1999) valgte at tilslutte sig den årlige kritik af Iran, da undlod man at stemme i den efterfølgende forsamling 54 (1999 - 2000), og siden er alle disse resolutionsforslag blevet forkastet af den russiske delegation.

I fem af de syv første afstemninger var Rusland faktisk det eneste af medlemmerne af Sammenslutningen af Uafhængige Stater (SNG), som kritiserede Iran, hvilket også indikerer, at det lå Kreml me- 
get på sinde at kæmpe for liberale værdier. Det er som vist skiftet siden, og det er tankevækkende, at ændringen i forhold til fx Iran falder sammen med Putins entre i toppen af russisk politik (premierminister 1999 og præsident siden 2000).

Min egen forskning i stemmemønstrene i generalforsamlingen viser i øvrigt, at de øvrige SNG-medlemmer ikke lader sig kontrollere af Rusland. Der er sket en tilnærmelse henover årene, men den skyldes primært ændringerne i den russiske politik, som altså er bragt tættere på de andre SNG-landes gennemsnitlige præferencer. Men man kan også se, at flere af Ruslands vigtigste allierede nu faktisk har et stemmemønster, som er tættere på Kinas end på Ruslands; det gælder fx for Hviderusland og Kasakhstan, og det må give anledning til bekymring i Moskva, at disse lande ikke i højere grad følger det russiske eksempel, og at forskellen udstilles på gulvet i Generalforsamlingen.

\section{Responsibility to Protect}

Rusland støttede slutdokumentet fra FN's World Summit, afholdt i New York i september 2005, og godkendte således også artiklerne 138-139 i dokumentet, som beskriver hhv. den enkelte stats forpligtelser og Sikkerhedsrådets rolle under Responsibility to Protect (R2P). I sin tale til forsamlingen af stats- og regeringschefer nævnte Putin helt bevidst ikke R2P, men talte derimod om vigtigheden af FN generelt og sikkerhedsrådet specifikt. Man fornemmede således, at dokumentets artikel 139 var den vigtigste for Rusland, og i dette lå måske et forvarsel om det, som senere skulle følge.

Allerede på dette tidspunkt talte man i russiske politiske kredse meget om vigtigheden af at respektere den ufortyndede westfalske suverænitet - det 'suveræ- ne demokrati' var vejen frem, sagde man - og det kan på den baggrund virke overraskende, at Rusland tilsluttede sig ideen om R2P. Deri ligger måske mest af alt en illustration af det enorme pres, der lå på FN's medlemslande for at finde en løsning, som kunne forhindre en gentagelse af udrensningerne i Rwanda (1994) og Srebrenica (1995), og som fik stater som Rusland til at gå med, selvom R2P kolliderer med andre dominerende normer som $\mathrm{fx}$ statens autonomi i beslutningstagning.

De russiske myndigheder lægger i dag ikke skjul på, at de betragter praksis i forhold til R2P med stor skepsis. Således noterer det russiske udenrigsministerium, at enhver beslutning om intervention skal tages af Sikkerhedsrådet, og der advares om tendensen med at gå uden om Sikkerhedsrådet og i stedet alliere sig med 'gruppen af venner' for på den måde at vinde legitimitet for sine aktioner.

Det er især den NATO-ledede intervention i Libyen, godkendt af Sikkerhedsrådet i Resolution 1973 (2011), som ifølge Rusland er et skræmmeeksempel på, hvor galt det kan gå, når R2P misbruges til fremme af egne interesser. Efterfølgende har man så besluttet, som det åbent erklæres via udenrigsministeriet, at " $i$ fremtiden vil Rusland ikke godkende (...) resolutioner, som sanktionerer væbnet intervention eller kamphandlinger uden en grundig overvejelse af parametrene for deres implementering. Der kan ikke være nogen blankocheck". Det er dårligt nyt for støtter af R2P.

På tidspunktet for godkendelsen af Resolution 1973 og de senere operationer i Libyen var Putin premierminister, mens det var Dmitrij Medvedev, som midlertidigt var blevet forfremmet til præsident. Netop spørgsmålet om Libyen skabte faktisk gnidninger mellem de to, og Putin advarede Medvedev mod konsekvenserne 
af at tillade interventionen. Rusland valgte ikke at blokere for resolutionen, og det skabte senere et internt rivegilde, hvis udfald nu afspejles i den ovenstående erklæring fra udenrigsministeriet. Medvedev spurgte senere retorisk, "hvorfor taber russiske firmaer altid, når der er et regimeskifte?", og det var klart, at han havde mødt stor modstand i vide kredse i den russiske top, og måske følte han sig endog svigtet af USA og andre ledende lande i koalitionen. Uanset hvad var det Putins linje, som triumferede, og han insisterer på suverænitet frem for humanitær støtte.

Og dog. For siden er spørgsmålet om de russisksindede blevet stadig mere centralt, og Rusland definerer det i dag også som en del af sin mission at beskytte denne lidt uklare gruppe. Senest så vi det i forbindelse med annekteringen af Krim i marts 2014, hvor russiske tropper blev sendt ind i Ukraine for, som man sagde, at forhindre overgreb på netop de russisksindede. Man har taget essensen af R2P til sig - at suveræniteten kan krænkes, hvis en stat ikke formår at beskytte sig egen befolkning eller måske endog aktivt undertrykker denne - og bruger den til at fremme russiske interesser. Det er endnu et aspekt af Ruslands kløgtige brug af 'normativ magt', de- fineret her som evnen til at definere acceptable standarder.

Budskabet fra Moskva vil være 'I startede det!', og det vil være vanskeligt for såvel Vesten som værtslandet at afvise de russiske argumenter, når der henvises til behovet for at forhindre massive overgreb, og når repræsentanter for de 'undertrykte' åbent anmoder Rusland om hjælp.

De politiske omvæltninger i Georgien (2003), Ukraine (2004 og 2014) og Kirgisistan (2005) foruden også det arabiske forår (2010 - 2012) har, sammen med regimeskiftene i Irak (2003) og Libyen (2011), cementeret Ruslands modvilje mod drastiske omvæltninger. I de førende politiske kredse i Moskva er R2P reduceret til et redskab for netop dette, og vi skal derfor forvente fortsat modstand mod at lade sikkerhedsrådet sanktionere interventioner. Rusland vil altså nedlægge veto mod sådanne forslag.

Modsat skal vi forvente, at Rusland i stigende grad vil gøre essensen af R2P gældende for sin egen politik og trække dette normative kort i forhold til alle de tidligere Sovjetrepublikker, hvis det skønnes formålstjenligt. 


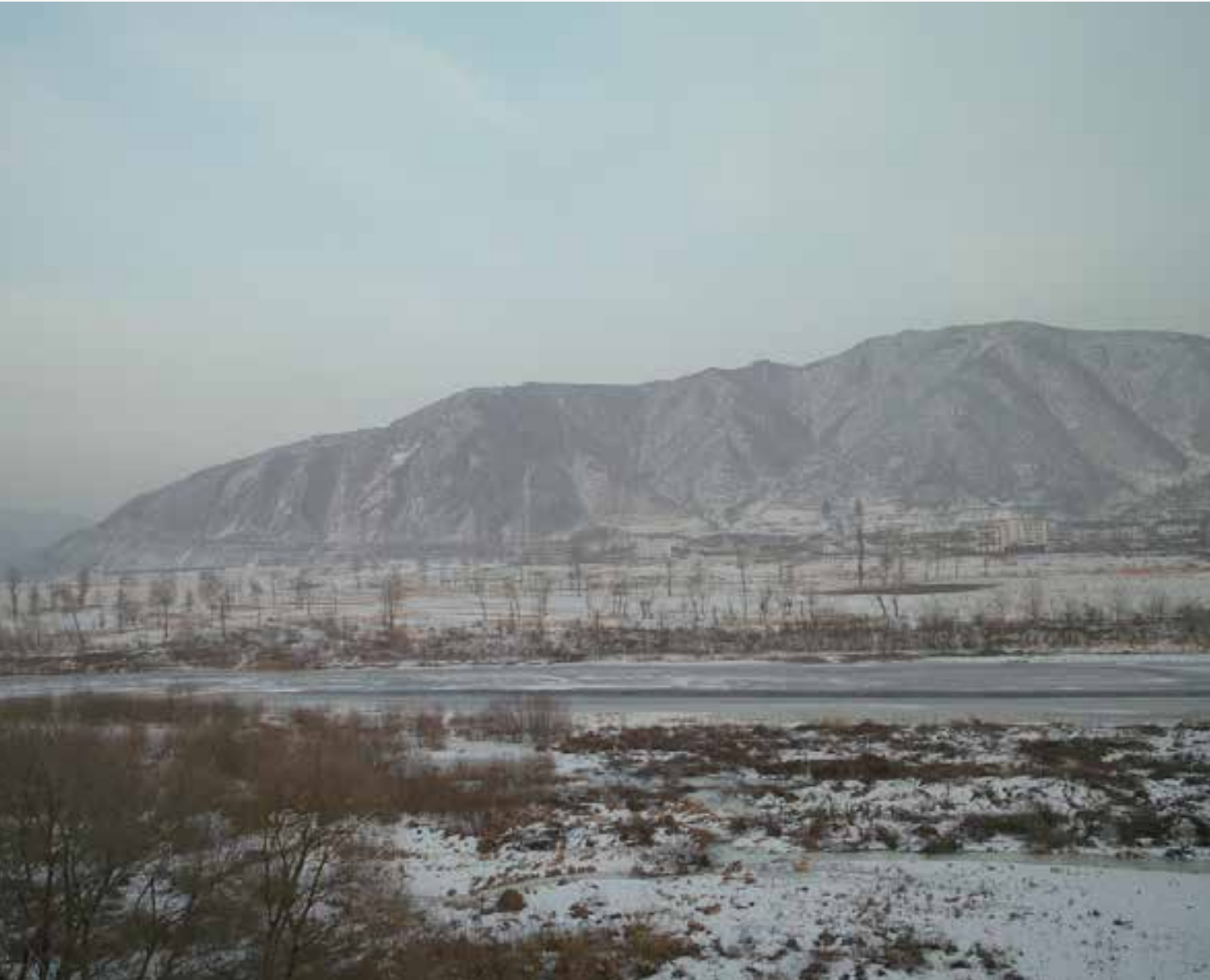

FOTO: Foto: Farm, via Wiki Commons

Tumen River på grænsen mellem Nordkorea og Kina set fra den kinesiske side. I december 2014 havde 10 vestligt orienterede medlemslande i sikkerhedsrådet bedt om, at Nordkorea kom på dagsordenen, men Kina argumenterede for, at omfattende menneskerettighedsovertrædelser i Nordkorea ikke udgør en trussel mod international fred og stabilitet og dermed ikke begrunder, at spørgsmålet tages op i sikkerhedsrådet. 